\title{
PKM Improving Capability of Madrasah Teachers in Implementing Classroom Research in Probolinggo
}

Moh. Fachri ${ }^{1}$, Yuni Safitri ${ }^{2}$, Yuni Permata Sari ${ }^{3}$, Nurul Jamila ${ }^{4}$, Intan Permata Sari ${ }^{5}$, Rohmah ${ }^{6}$

Universitas Nurul Jadid, Probolinggo, Indonesia 1,2,3,4,5,6

\{mohammadfahri787@gmail.com 1,2,3,4,5,6\}

\begin{tabular}{ll}
\hline Submission: 19/12/2021 Received: 31/12/2021 Published: 31/12/2021 \\
\hline Keywords: & Abstract. Teachers as a professional staff should have the ability to \\
Keywords: & analyze the problem on the kids, and it has become the study to solve \\
professionalism; & problems students through classroom research. But most teachers \\
school; & have not known enough to develop a research proposal class action. \\
classroom & Teachers' low-level knowledge in doing classroom research is one of \\
research & the problems in contemporary education. This community service is \\
& to equip teachers to implement classroom research. This study aims \\
& to make most teachers understand classroom research and figure out \\
& how to arrange good classroom research. The benefit of this \\
& community service was that teachers were able to make \\
& proposals/proposals for classroom research good and under the \\
& proper format and give the idea of a follow-up to teachers after \\
composing classroom research proposals. The purpose for teachers \\
on the procedure writing classroom research is that they are \\
motivated to write classroom research. Asfor the result of assistance \\
and changes in conclusion as follows: 1) able to identify problems in \\
learning in class. School teachers can also solve a problem by \\
solutions that they consider strategic through learning innovative \\
methods. 2) school teachers can describe identification problems in \\
the background problems and determine the title research will be \\
classroom research. School teachers also have been able to prepare \\
the theory according to the title research will be implemented. 3) \\
school teachers can arrange research procedures consisting of \\
planning, research, observation, and reflection. 4) school teachers \\
can learn according to learning preparation every cycle. 5) school \\
teachers can arrange research reports on classroom action in the \\
scientific article.
\end{tabular}

Katakunci:

Kata kunci:

profesionalisme; sekolah; penelitian kelas
Abstrak. Guru sebagai tenaga profesional harus memiliki kemampuan untuk menganalisis masalah pada anak, dan telah menjadi pembelajaran untuk memecahkan masalah siswa melalui penelitian kelas. Namun sebagian besar guru belum cukup tahu untuk mengembangkan proposal penelitian tindakan kelas. Rendahnya pengetahuan guru dalam melakukan penelitian kelas merupakan salah satu permasalahan dalam pendidikan kontemporer. Pengabdian kepada masyarakat ini untuk membekali para guru dalam melaksanakan penelitian kelas. Penelitian ini bertujuan untuk membuat sebagian besar guru memahami penelitian kelas dan mencari cara untuk mengatur penelitian kelas 
yang baik. Manfaat dari pengabdian masyarakat ini adalah guru dapat membuat proposal/proposal penelitian kelas dengan baik dan dalam format yang tepat serta memberikan gambaran tindak lanjut kepada guru setelah menyusun proposal penelitian kelas. Tujuan bagi guru tentang prosedur menulis penelitian kelas adalah agar mereka termotivasi untuk menulis penelitian kelas. Adapun hasil pendampingan dan perubahan kesimpulan sebagai berikut: 1) mampu mengidentifikasi permasalahan dalam pembelajaran di kelas. Guru sekolah juga dapat memecahkan suatu masalah dengan solusi yang mereka anggap strategis melalui metode pembelajaran yang inovatif. 2) guru sekolah dapat mendeskripsikan identifikasi masalah yang melatarbelakangi masalah dan menentukan judul penelitian yang akan dilakukan penelitian kelas. Guru sekolah juga telah mampu mempersiapkan teori sesuai dengan judul penelitian yang akan dilaksanakan. 3) guru sekolah dapat menyusun prosedur penelitian yang terdiri dari perencanaan, penelitian, observasi, dan refleksi. 4) guru sekolah dapat belajar sesuai persiapan pembelajaran setiap siklusnya. 5) Guru sekolah dapat menyusun laporan penelitian tindakan kelas dalam artikel ilmiah.

\section{Introduction}

Improving teacher competence is a crucial part of the world of education. Competencies consist of knowledge, skills, and behaviors that must be possessed, internalized, and mastered by the teacher in carrying out his professional duties. As part of a learning agent at the basic education level and secondary and early childhood education, a teacher must have academic, personal, professional, and social competencies. In this case, a teacher must master teaching skills. In the teaching-learning process, the teacher plays a role as a director and an actor and is a factor that is very dominant in determining the success of the learning process in class. (Sutarmanto, 2015) teacher professionalism must be improved because the teacher has an essential role in improving the quality of human resources. Teachers can make some efforts to understand the minimum standards of qualifications and competencies, improve service-based work, and enhance creativity in using the latest information and communication technology (Muhson, 2004).

In its development, the world of education is required to produce human resources (HR) under progress technology. Teachers should have an essential role in education so that almost all reform efforts in the field of education depend on the teacher. Teachers should master lesson materials, teaching and learning strategies, encouraging students to learn to achieve high performance. In practice, the teacher is the spearhead, so it needs the 
professional development of teachers. Every teacher has the potential and needs to develop and realize himself. The result of science and technology requires teachers to carry out work professionally. An elementary school teacher must have four competencies: pedagogic, personality, social and professional (Supriadi, 2009).

Developing the four competencies above is not easy for teachers to have. Teachers always practice doing portfolio assessments of the learning process carried out in class. This practice is often forgotten in writing scientific reports. One of the efforts that need to be done is increasing teacher professionalism in writing, especially the scientific writing movement. It is in line with the Law of the Republic of Indonesia No. 142005 article 20 part b, which states that in carrying out professional duties, the teacher is obliged to improve and develop academic qualifications and competencies on an ongoing basis in line with the development of science, technology, and art.

Among the competencies teachers must possess, skill writing, especially scientific papers, is a part of academic competencies. Teachers who cannot write well will experience various problems in writing communication. In carrying out their daily duties, teachers are required to write a job application letter, write official letters, write reports on an activity, and most important,y writing scientific papers for promotion (Cf. Keraf, 1996). The education law implies the importance of competence a teacher must-have. Even to support teachers get a very open opportunity to compete to get additional welfare through increasing functional position of a teacher on the condition that he must develop self-competence and get an assessment through increasing credit scores for every development carried out. But there is a massive obstacle seriously related to increasing self-development, namely the need to make scientific papers, especially teachers who want to improve their functional positions.

To improve the quality of education, especially the level of Probolinggo district and city madrasas need a program increasing teacher professionalism through PBM training, Competency Test Teachers, training in learning evaluation, and research. Study Classroom actions give quite important meaning to the teacher as a teacher means of improving the quality of learning by applying innovative learning methods. Through this activity, the teacher can concretely describe some of the problems he experienced in the 
learning process and analyze problems by determining innovative learning methods that are appropriate for overcoming the difficulties. At the end of a classroom action research, an analysis to make the conclusion and research recommendations is needed. Thus, the teacher will continue to analyze the problems obtained in the learning process and find solutions.

However, based on the researcher's observations and interviews with several principals, the madrasa teacher's enthusiasm is still lacking in researching this class action. This lack of motivation is due to limited capabilities and the teacher's research experience. Madrasa teachers inThe Probolinggo Regency and City Environment have never received classroom Action Research Writing training. In 2015, throughTheir Ministry of Religion only got a teacher's professional guidance on teaching and research methodologies of scientific papers in general. So, conducting classroom action research is essential limited and less than optimal.

Some of the results of classroom action research made by several teachers to get a credit score are still straightforward and reflect the concept of classroom action research. Their ability to describe and analyze less than optimal problems affects the learning methods and research procedures. Thus the final result of the exposure of each cycle research does not convey any significant changes quite significantly.

\section{Method}

Islamic High School Probolinggo, as an educational institution and education personnel, has a stake in efforts to improve the quality of education in general and improve the quality of human resources through service activities in society. The Institute for Research and Service to the community (LP2M) seeks to establish cooperation with several schools partners, either elementary level or $\mathrm{Ml}$ to intermediate level or MA. Currently, LP2M Universitas Nurul Jadid Probolinggo has collaborated with 20 educational institutions from TK/RA, SD/MI to SMA/K/MA, both district and city of Probolinggo. Forms of Cooperationcarried out, among others, is the development of teacher professionalism such as assistance in teaching preparation, innovative learning, and scientific writing. 
One of the efforts to develop teacher professionalism is that can be done at this time is Training and Assistance in the preparation of classroom action research. Because of this, training and mentoring have many benefits for teachers to practice writing and describing problems, analyze, and try to find solutions to the actions to be taken to optimize the learning process in the classroom. Thus TitleThis proposal is "Improving the Ability of Madrasah Teachers in Conducting Classroom Action Research in Probolinggo."

\section{Result and Discussion}

\section{Condition of Assisted Subjects}

The community service location that will be carried out is 17 Madrasas that have collaborated with LP2M Universitas Nurul Jadid Probolinggo. The distance from the service location to the LP2M institution ranges from 1-15 $\mathrm{Km}$, which can be reached by motorbike in 10 minutes to 1 hour. The number of teachers involved in this research is 20 people. In general, in terms of quantity, the presence of madrasa teachers in Probolinggo Regency and City can say it is sufficient. However, in terms of quality, the condition of madrasa teachers is still far from expected, especially for private madrasas. The observations show that several madrasa teachers who teach certain subjects are not under his competence. There are still madrasa teachers who have not completed S1 studies. In the learning process, in general, there are still many madrasa teachers who carry out the learning process using conventional and classical methods, and it is one-way. Almost 90\% of the learning methods used are lecture methods.

This phenomenon caused low motivation and interest for students. As a result, schools' minimum completeness criteria $(\mathrm{KKM}=70)$ are difficult to fulfill. In the end, the teacher tried to adjust student scores on the KKM without going through the process of remedial and re-evaluation. Teachers do not carry out self-evaluation of the learning process carried out.

The interviews with researchers to several madrasas partners LP2M Universitas Nurul Jadid Probolinggo found several facts, including many teachers do not understand innovative learning methods such as cooperative learning and contextual teaching. Collaborative learning consists of Jigsaw, STAD, Numbered Head Together, Team Game Tournament, Say to Stray. In 
contrast, contextual teaching consists of Learning together, Learning community, Discovery Learning, and others. These two innovative learning methods are rarely used, never even at all, because they generally can't do the learning steps.

Likewise, with the ability to write Classroom Action Research, 50 questionnaires were distributed to 18 madrasas that we partnered with In this study, there were only three teachers who had conducted classroom research. The LP2M team's review of the classroom action research shows that the quality of report of the teacher classroom research is still far from perfect both in the formulation of background, research methodology, and procedures research. This weakness is because madrasa teachers have never attended classroom Action Research workshops and training conducted by the Ministry of Religion and universities.

Member of Universitas Nurul Jadid Community Service team, Probolinggo, has a strong desire to carry out the mandate and maximize performance to establish empowerment programs assisted communities with passion and sincere intention to improve quality and quality of assistance, especially the madrasa community. Team members involved in this activity have had sufficient experience to carry out this service program - the researcher also as a lecturer in Class Action Research courses and Participatory Action Research.

In addition, the resources that are owned in running this program are the strong will and determination of the Community Service Team Universitas Nurul Jadid Probolinggo assisted with motivation and community assistance and people who want change towards a better good. Other resources in this empowerment program are strong commitment and support from the Government and MoRA, Diknas, and other educational institutions, nongovernmental organizations (NGOs), and other community organizations that participate and provide the smooth contribution.

Our team consists of seven people who work as lecturers still Universitas Nurul Jadid Probolinggo. We have a shared commitment to advance the nation's children in fast-paced globalization and full of challenges. So Islamic educational institutions, especially madrasas, should carry out selfimprovement to strengthen existentially and prepare alumni to respond to existing changes. In addition, madrasa education is limited to the transfer of 
knowledge and must be interpreted as forming good moral and social attitudes. That's when education as a system and as a sub-culture will actually have power as an agent of change. But in reality educators who function as the main facilitators of success do not yet have the appropriate skills and knowledge with the demands and mandate of Law No. 20 of 2003 concerning the national education, Law No. 13 of 2005 concerning Teachers and Lecturers, PP No 16 of 2007 concerning Academic Qualification Standards and Government Regulation No. 18 Years 2008 concerning Teacher Certification in Position.

Our capacity in CAR assistance and training is as a facilitator, namely facilitating the assisted community to find the problems encountered then map and planning the program, implementing and evaluating the program plan empowerment related to Classroom Action Research that related to learning, managing research procedures, how the program is implemented, what is needed to implementing the program to program evaluation.

\section{Condition of Expected Subjects}

Classroom Action Research is a research activity with observing a learning activity that is given action deliberately raised in a class, which aims to solve problems or improve the quality of learning in the classroom. It is hoped that CAR teachers can collaborate with colleagues in designing, implementing, and reflecting collaborative and participatory actions. For teachers who are busy in everyday life, the teacher does not realize that he too needs to increase their professionalism through research that can carry out directly on learning activities in class. So those activities learning in the classroom do not watch using the conventional learning method but prioritize innovative and fun learning.

From training and research assistance Classroom actions that will be carried out, first, the madrasa teacher will know about innovative learning. This creative learning will give nuance new for teachers and students to create a comfortable learning environment pleasant so that the interest and motivation of students will increase to follow every material that the teacher will teach. As a form, the correlation between student learning outcomes that the school has determined through the KKM can be met with optimal. 
Second, madrasa teachers are expected to know classroom action research methodology, CAR implementation, and CAR report under the planned research procedure. The implementation of classroom action research will allow Madrasah teachers to analyze problems in learning and try to find solutions through innovative education.

Third, improve the quality of madrasa educational institutions to become educational institutions that have good quality values. Therefore, the community will give the madrasa full trust in professional education management.

From training and research assistance, classroom actions that will be done is an improvement or improvement (improvement and improvement) therapy), including:

a. Improvement or improvement of student learning performance in schools;

b. Improvement or improvement of the quality of the learning process in the classroom;

c. Improvement or improvement of the quality of the use of media, tools study, and other learning resources;

d. Improvement or improvement of the quality of evaluation procedures and tools used to measure the process and student learning outcomes;

e. Improvement or improvement of children's education problems in school;

f. Improvement and improvement of the quality and competence of students in schools.

Probolinggo Regency and City Madrasah Teachers have a strong passion and consistency to develop themselves as community mentor. This Self Development is a basis to promote and improve the quality of graduates to provide a real contribution to the development of science and technology and art and various problems that exist in society.

This program would not be possible without your support and cooperation between the related parties, the proposing agency, assisted communities, Directorate General of Islamic Higher Education Ministry of Religion of the Republic of Indonesia, and parties who help the achievement of this program.

Activity Training and Mentoring Society started from October 29 to November 8, 2016. For Consolidation material for the service, participants to 
participate in the workshop for three days beginning on 29 October-1 November 2016 at STAIM Hall Building starting at 07.30 until 16.00 WIB. While November 2 to November 8, Assistance is carried out at the Madrasa in question to implement Classroom action research. This activity was attended by 20 participants from 18 Madrasah Representatives in Probolinggo Regency and City.

The study uses the PAR method, which is characterized by participatory and using the mentoring cycle, researchers provide sufficient opportunities to Madrasah teachers to carry out the activities that have been specified in the schedule of activities. Through activities in several processes, the teacher will be able to change himself from not being able to do this by conducting and publishing classroom action research. A teacher professional can carry out and write classroom action research well.

Based on the priority of the types of activities above, the implementation of this activity is carried out periodically. Based on the schedule above, this training is arranged coherently in 5 (five) stages.

First, at the beginning of the training, the teacher explained writing scientific papers by Ulil Hidayah, M. Pd.I. This material is essential to provide primary reinforcement to teachers in writing essays science in general. In this material, the resource person gave a lot of emphasis on systematic writing and retrieval of library resources. Some participants were quite enthusiastic about consulting some findings as an article or research in the presentation session. As stated by Mr. Hari Basuki, S. Pd from MAN 1 Probolinggo City, from several experiences, what he has done has given a lot of results from the process of entrepreneurial learning for students. This aspect of success can be seen from the teaching and learning process and the produced products. Hari Basuki, S. Pd proposed recommendations for resource persons to determine what type of research is appropriate to meet the feasibility made into writing.

The second stage in this material is the Innovative Learning Method conveyed by Ahmad Philip, M. Pd., M. Si. This material is essential to be understood by the trainees remembering that research classroom action requires innovative learning methods and models to overcome various problems in the learning process. Some models offered in this material are cooperative learning and contextual learning teaching. 
The third stage is the Mendeley-Desktop-1.14-Application win32. This application assists teachers in writing sources library quickly, both from Journals and from e-books. At the meeting, the training participants were introduced to several online journals and Easily accessible e-books to strengthen the theoretical foundation in writing CLASSROOM RESEARCH. Introduced several methods of searching for materials in various formats with ease. Because based on the initial spread questionnaire to training participants, almost $70 \%$ of teachers find it challenging to explore the theoretical basis that must be used.

The fourth stage is CAR material delivered by Benny Prasetiya, M. Pd. I. At the initial stage, participants discuss the basic concepts of CLASSROOM RESEARCH with the speaker. From this discussion, it can be seen that participants have not fully understood the idea of classroom action research. Almost All participants have never done classroom action research. Step problem solving by resource persons is to make a matrix CAR writing worksheet. The rubric contains problem identification, reasons for choosing learning methods, research titles, problem formulations, research objectives, and theoretical studies. Next, participants fill in the method research and procedures to be carried out. To make it easier for participants, the resource person gave several examples of CAR writing so that the trainees have a real systematic picture of good CAR writing and formatting. The final result of this activity is that the teacher can make a title and develop the background of the problem, formulate the problem, and research purposes. Participants can create a theoretical framework that can support research and answer issues. Apart from the two results mentioned above, participants can also design research procedures, instruments, and data analysis.

The fifth cycle is Classroom Action Writing Assistance. At this stage, participants receive intensive guidance from the Team Community service in formulating a classroom action research. They started by exploring problems in the good learning process, student learning motivation, learning outcomes, and teaching preparation. At this stage, participants are expected to describe several reasons fundamental to the implementation of Classroom Action research. Multiple identification problems are found, then formulate methods and learning strategies used in problem solving learning. The service team provides direction for several systems learning under the issues faced 
by each participant in the learning process. By finding identification problems and learning strategies, the trainees try to formulate the Class Action Research title to be implemented. Next, the service team assists participants in writing theoretical studies using the Mendeley application to make it easier for teachers to take library resources in several e-Journals and e-books. Because so far, one of the obstacles faced by teachers in conducting classroom action research is the lack of access references they have. Regional Libraries in Probolinggo are very limited in providing educational books, especially about learning methodology. The solution is the teacher looks for some learning methodology references in e-journals and e-books. This process is continued with the writing of the research methodology. In this research methodology, the focus of the mentoring team is to direct teachers in writing research procedures that will be carried out in the implementation of CAR in the classroom. The teacher prepares process planning, learning, implementation, evaluation, and reflection to be carried out.

The sixth cycle is Classroom Action Implementation Assistance. The final stage in this activity is Mentoring implementation of classroom action research conducted by teachers in madrasas. In the fifth cycle, the teacher has determined the time implementation of classroom action research each cycle. The service team adjust the time of implementing the Class Action Research that teachers will implement in madrasas. This stage is very useful for teachers to find some of the obstacles that teachers experience in the implementation of CAR, especially observing colleagues who become a reference for teachers to analyze the development of activities and results student learning each cycle.

Teacher professional development is closely related to activities research, especially Classroom Action Research (CAR), as material compiling Scientific Writing (KTI). CAR is essentially an activity of scientific research that can be used as reflection material for activities. Learning in class is scientific and accountable.

Because CAR is research conducted by the teacher in their class themselves based on their problems, teachers can collaborate with peers in designing, implementing, and reflecting on collaborative and participatory action through classroom research. That matter becomes a problem for teachers who are busy with their daily activities. Teachers are less aware that 
they also need to increase their professionalism through research that can be done directly on learning activities in class.

Writing a Classroom Action Research proposal (CAR) is a pretty tough thing to do for most teachers. The weight category they feel basically because of their lack of understanding about how to write a systematic and easy CAR proposal through five stages of writing a CAR proposal: (1) presentation of material about an overview of CAR which includes the definition of CAR, benefits of CAR, components in CAR, steps to implement CAR, (2) Introduction about the CAR proposal which includes the CAR proposal format, systematics CAR proposal, and most importantly the content of the CAR proposal, (3) Preparation of CAR CAR proposal by the teacher in groups, at this stage the author provide examples of finished CAR as well as internal signs preparation of CAR, (4) Introduction to instrument making and analysis data after the CAR has been carried out, (5) a review of the training that has been implemented and concluded.

The products produced in this activity journal articles of results classroom action research. Journal articles of research results produced by teacher assessed. Assessment of reports using instruments in sheets evaluation of journal articles of Classroom Action research results. The assessment sheet on the quality of the resulting research journal articles.

The research uses the PAR method characterized by participatory and using an accompanying cycle. In this mentoring cycle, scientific discussion. The class action is divided into four training activities and research assistance processes. The cycle of speakers provide opportunities for all participants to conduct meetings and ask and answer questions from the material that has been presented. Participants were very enthusiastic about participating in every scientific discussion each year cycle. The following is a description of each of the scientific talks:

Training and mentoring Writing research Action this class provide space for madrasa teachers to have the ability to conduct Classroom Action research reports. Because in essence, in fact, teachers often do action research in class but do not continue at the reporting stage. The process of researching what a teacher does daily finally can produce a work called classroom research. It can occur when a general sequence of procedures, i.e. starting from identification, research problems faced up to the final report 
noted. So, this procedure must be understood and obeyed by the teacher who researched.

Research in education does require several instruments (toolbox) consisting of various approaches to assessing multiple educational issues in our society. Formal education limits itself to experiments or research that only relate to the curriculum or the problems revealed in textbooks. Educational practice should breakthrough more to real life, inviting students to think when he learns and learns more to think more deeply about various problems in life or the environment. These problems will open our minds to finding multiple solutions to overcome multiple learning gaps through the different ways described.

By understanding and paying attention to the characteristics of each student, then the teacher will be able to develop the unique potential possessed by each student by performing various actions that are included in the classroom action research (CAR). Through CAR designed by the teacher, teachers are expected to discover the unique potential of students, which leads to improved learning outcomes.

The results of this classroom action research training show that $100 \%$ of 20 participants were motivated to carry out classroom action research and completed the CLASSROOM RESEARCH report of the 20 participants who can complete classroom action research and reporting. All participants said that this in-on-in training gave them the necessary guidance to perform analysis and reporting. Their activity was useful in building knowledge and skills about classroom action research. They also said that knowledge and skills to carry out their research could also be applied to study other than CAR.

The participants felt that the in-service learning 1 activity was very useful in building their knowledge and understanding of classroom action research concepts. The delivery method of the varied material is very fun and not boring. The participants also said that they can build good cooperation even outside of training because training is always carried out inside the group.

Activity on the job learning is the most preferred participant of CAR training with this In-on-in model. Activities that last for approximately three months provide enough time for participants to apply the research theories obtained in in-service learning 1 . Moreover, the activities on the job learning 
this equipped with mentoring and monitoring activities carried out by the facilitator during on the job learning activities. Participants feel monitoring and mentoring activities are very useful in guiding and monitoring the implementation of their tasks, namely conducting classroom action research and compiling the report in the form of a CLASSROOM RESEARCH report.

The supporting factor for this activity is the motivation to participate in LP2M activities. In addition, the teacher's ability to operate a computer is very helpful and makes it easier to implement and write research journal articles. Supporting factors that are not less important is the support from the Head of the Buleleng Sub-district UPP, para supervisors in the Buleleng District, and partner school principals.

Although this activity has been carried out well, there are also obstacle factors. The inhibiting factors encountered included: (1) para the teacher has never written a research journal article, so at the beginning, it's a bit hard to accompany him and (2) the teachers are busy to follow various activities, and the implementation of various tasks is quite difficult to carry out article writing assistance.

Teacher professional development is closely related to activities research, especially Classroom Action Research (CAR), as material compiling Scientific Writing (KTI). CAR is essentially an activity of scientific research that can be used as reflection material for activities. Learning in class is scientific and accountable.

CAR is research conducted by the teacher in his class themselves based on their problems. Through CLASSROOM RESEARCH, it is hoped that teachers can collaborate with peers in designing, implementing and reflecting on collaborative and participatory action. That matter becomes a problem for teachers who are busy with their daily activities. Teaching teachers are less aware that they also need to increase their professionalism through research that can be done directly on learning activities in class.

The products produced in this activity journal articles of results classroom action research. Journal articles of research results produced by teacher assessed. Assessment of articles using instruments in sheets assessment of journal articles of Classroom Action research results. The assessment sheet on the quality of the resulting research journal articles. 
The research uses the PAR method characterized by participatory and using an accompanying cycle. In this mentoring cycle, scientific discussion. The class action is divided into four training activities and research assistance cycles. Each process of speakers provides many opportunities for all participants to conduct conferences and ask and answer questions from the material that has been presented.

\section{Conclusion}

The condition of madrasa teachers in conducting research writing Class Actions, especially Probolinggo as an assisting locus, among others that the ability to write CAR is very low. It is based on very minimal results of classroom action research owned by teachers. From 20 trainees who have conducted and written research reports, classroom action is only one person or $5 \%$. The teacher's incompetence in Doing Classroom Action Research writing is caused by: the lack of knowledge that madrasa teachers have in preparing and carrying out classroom Action research and motivation to write. Even though the results of initial observations, the response of the madrasa teacher's desire to do quite large Class Action research and hoping for training and the assistance that will be carried out can motivate them to carry out CAR.

To change the condition of Madrasah Teachers, the PAR ( Participatory Action Research) method is used. With this method, it is hoped that it will be useful to facilitate and motivate madrasa teachers to identify strengths and weaknesses in the learning process to make further the basis for in conducting classroom action research, developing strategies and methods appropriate for solving problems in learning up to achieve the expected target under the KKM.

Through several stages of the activity cycle, starting from planning, implementation, observation, and reflection implemented on the subject assisted by madrasa teachers. The assistance/changes that occur can be concluded as follows: 1) Able to identify problems in the learning process in the classroom. Madrasa teachers are too able to solve problems with their solutions considered strategic through innovative learning methods. 2) Madrasa teachers can identify problems in the background behind the problem and determine the title of the research that will be used Classroom 
action research. Madrasa teachers also can develop a theoretical basis under the title of the research to be implemented. 3) Madrasa teachers can develop research procedures consisting of planning, implementation of research, observation, and reflection. 4) Madrasah teachers can carry out the learning process by the Learning preparation design for each cycle. 5) Madrasa teachers can compile Classroom Action Research reports in the form of scientific articles.

\section{References}

Chakhshi, S., Clea, F. (2004). Cellenger to Importing Japanes Lesson Study. Bloomington Concerns, Miscoseptions, and Nuancen. www.proquets.umi.com.

Chakhshi, S., Clea, F. (2005). Reaping the Systemic Benefits of Lesson Study Bloomington: Insights from the U.S. Vol 86. www.proquets.umi.com.

Departemen Pendidikan Nasional. (2005). Peraturan Pemerintah Nomor 19 Tahun 2005, tentang Standar Nasional Pendidikan, Jakarta: Depdiknas.

Departemen Pendidikan Nasional. (2005). Undang-Undang Nomor 14 Tahun 2005, Tentang Guru dan Dosen, Jakarta: Depdiknas.

Departemen Pendidikan Nasional. (2007). Peraturan Menteri Pendidikan Nasional Nomor 07 Tahun 2007, tentang Organisasi dan Tata Kerja Lembaga Penjamin Mutu Pendidikan, Jakarta : Depdiknas.

Departemen Pendidikan Nasional. (2007). Peraturan Menteri Pendidikan Nasional Nomor 16 Tahun 2007, tentang Standar Kualifikasi Akademik dan Kompetensi Guru, Jakarta: Depdiknas.

Inagaki, T. and Sato, M. (1996). Jugyo Kenkyu Nyumon (Introduction to Lesson Study. Tokyo: Iwanami.

Kemmis, S. and McTaggart, R. (1988). The Action Researh Reader. Victoria, Deakin University Press.

Marsigit. (2007). Mathematics Teachers' Professional Development Through Lesson Study in Indonesia. Eurasia Journal of Mathematics, Science \& Technology Education, 3 (2), 141-144. 
Robinson N. (2006). Lesson Study: An example of its adaptation to Israeli middle school teachers. (Online): stwww.weizmann.ac.il/G-math/ICMI/ Robinson proposal.doc

Stephen L., T. (2007) Science Activities, Washington: Winter 2007. Vol. 43. Iss. 4, pg.27, 7 pgs.

Stewart, R, Brederfur, J. (2005). Fusing Lesson Study and Aithetic Achievent. Bloomington: A. Model for Teacher Collabooration. www.proquest.umi.com

Suhardjono, A. H., et.al. (1996). Pedoman Penyusunan Karya Tulis IImiah di Bidang Pendidikan dan Angka Kredit Pengembangan Profesi Widyaiswara. Jakarta: Depdikbud, Dikdasmen.

Suhardjono. (2010). Penelitian Tindakan Kelas. Makalah pada Diklat Pengembangan Profesi bagi Jabatan Fungsional Guru, Direktorat Tenaga Kependidikan Dasar dan Menengah, Direktorat Jenderal Pendidikan Dasar dan Menengah, Depdiknas.

Suhardjono. (2005). Laporan Penelitian Eksperimen dan Penelitian Tindakan Kelas sebagai KTI, Makalah pada Pelatihan Peningkatan Mutu Guru di Makasar, Jakarta, 2005

Suharsim, A., Suhardjono, dan Supardi. (2006). Peneilitian Tindakan Kelas. Jakarta: Bina Aksara.

William, C. and Kopp, B. (2006). Lesson Study as a Model for Building Pedogogical Knowledge and Improving Teaching. International Journal of Teaching and Learning in Higher Education. 18 (3), 150-257. ISSN 1812- 9129

Muhson, A. (2004). Meningkatkan Profesionalisme Guru: Sebuah Harapan. Jurnal Ekonomi \& Pendidikan.

Supriadi, O. (2009). Pengembangan Profesionalisme Guru Sekolah Dasar. Jurnal Tabularasa PPS Unimed.

Sutarmanto. (2015). KOMPETENSI DAN PROFESIONALISME GURU. Jurnal Tabularasa. 